\title{
A Procedure for Evaluating Primary Health Care Software
}

T Mc Donald

D.Phil (Mathematical Statistics)

Department of Computer Science

University of the Free State
$35 \%$ of the

\section{nurse's}

\section{worklood lends itself to}

\section{computerisation.}

\section{Research Article}

\section{fbstract}

Managers in health care often find themselves in the difficult position of having to make decisions regarding the purchasing of software and hardware which they are not qualified to make. The aim of this paper is to support health managers in their decision making by means of a procedure and an instrument that can be used to evaluate primary health care software. A seven step approach to the evaluation process is proposed and each step is discussed in detail. The paper concludes with a proposed software evaluation instrument that is suitable for application in the health care environment.

\section{Cittreksel}

Bestuurders betrokke in gesondheidsorg bevind hulleself dikwels in die moeilike posisie om besluite te neem ten opsigte van die aankoop van programmatuur en apparatuur waarvoor hulle nie opgelei is nie. Die mikpunt van hierdie artikel is om bestuurders in gesondheidsorg te ondersteum met hulle besluitneming deur middel van ' $n$ prosedure en instrument wat gebruik kan word om primêre gesondheidsorg-programmatuur te evalueer. ' $n$ Sewe stap benadering tot die evalueringsproses word voorgestel en elke stap word breedvoerig bespreek. Die artikel eindig met ' $n$ voorgestelde instrument vir programmatuur-evaluering wat geskik is vir toepassing in die gesondheidsorg-omgewing.

\section{Introduction}

Nurses providing primary health care (PHC) services from stationary and mobile clinics carry an excessive administration burden. Several studies have shown that health care workers spend $40-50 \%$ of their working time compiling data for higher authorities (Moidu, Wigertz and Trell 1992:38). Other studies have indicated that as much as $35 \%$ of the nurse's workload lends itself to computerisation (Mc Donald, Chapman and MacKenzie 1994:38). Information technology can therefore play a major role in lightening the administrative burden of nurses and, in so doing, enabling them to provide quality patient care. Management will also benefit by having access to accurate and timely information. For these reasons several health care providers are considering computerisation of their services.

For those providers who have taken the decision to computerise, the options are to develop the computer programs inhouse (IT-department and qualified staff available), to obtain a contractor to do the development, or to buy a system that has already been developed. The last alternative, to purchase a system off-theshelf, is the one that will be discussed further in this paper because this is the situation that prevails in the health care environment. Usually several software packages are available and the "best" must be selected. Most of the managers who must make the decision to purchase a specific computer system, are not qualified IT experts and are not in the position to make the best choice. They can be influenced easily by persuasive salesmen who show them only what they would like them to see. Choosing the right software is a crucial decision for anyone considering new computer applications for an organisation because this decision can involve millions of rands, especially if the system is to be implemented on a national or provincial basis. Managers therefore need help in this complex and challenging endeavour in order to enable them to make decisions on an informed basis. It is in this regard that software evaluation techniques can be of tremendous help.

In the context of this paper software evaluation can be defined as the process by means of which health managers determine whether one or more available software packages can actually solve a health care problem. If several 
packages solve the problem, software evaluation will further assist the managers to select the "best" one. The purpose of software product evaluation is to provide management with quantitative results concerning one or more software products so that informed decisions can be made.

The actual software evaluation may be carried out by a computer expert, a team of reviewers, the users or a combination of the before-mentioned. The computer expert evaluates the different software packages in a "laboratory" situation. The main focus in this approach falls on the technical merits (data structures, program style, etc.) of the software. A team of reviewers usually consists of people who lack experience in informatics and computer technologies. For instance, in a health care environment the committee will consist mainly of nurses. At least one person who has knowledge of software and hardware capabilities is usually included in the committee. An evaluation committee is mostly used in situations where the software is only made available by vendors for a limited time. However, the results will be obtained if the users in a controlled field trail do the evaluation. In this case the nurses in the clinics test the computer system while they provide primary health care services. If at all feasible, this is the preferred method of evaluation.

\section{Research Objective}

The aim of this paper is to support health managers in their decision making by means of a procedure and an instrument that can be used to evaluate primary health care software in order to purchase the "best' software.

\section{Steps In The Evaluation Process}

Several different steps that should be followed during the evaluation process are reported in the literature (Martin and Trumbly 1986:13, Mosely 1992:30-31). The steps proposed in this document are to a large extent derived from these studies. The recommended steps are the following:

- Determine the objectives that the computer system must meet, the functions it must fulfil and the features it should have.

a Identify potential software packages that meet these objectives.

D Determine the key factors which contribute towards the achievement of the objectives.

- Establish an evaluation tool/instrument that consists of evaluation criteria for each of the key factors.

- Select a measurement method and the unit of measurement for the se- lection criteria.

apply the evaluation tool to each of the selected software packages.

Analyse the data and make recommendations by way of a detailed report on the result of the evaluation.

Each of these steps will now be discussed in more detail and applied to PHC software assessment.

\section{Objectives that the proposed computer system must meet}

The evaluation process starts with determining the objectives that the computer systems that are to be evaluated should meet. The nurses, or a representative committee of the nurses, should determine the objectives. If the users determine the objectives, they will later be in a good position to decide whether the system under evaluation meets these objectives. Each nurse can state what she expects of the computer system, what she believes it should do, what it should contain and how it should work. This is indeed a realistic wish list. This step is very important because it identifies and quantifies user needs and the required capabilities and features of the computer system.

\section{Selection of software packages}

The second step in the evaluation process is to survey the market for PHC software that meets the above-mentioned objectives. An expert can do this selection. He can also conduct a brief evaluation to ensure that only applicable software undergoes the detailed evaluation. If numerous software packages are available, an evaluation committee can do a screening of the packages and select three to five packages for a detailed analysis. Allowing all the vendors a specific amount of time to demonstrate their products can do this. A brief evaluation can then be done, based on the demonstration and a few other criteria.

\section{Identification of key factors (sub-systems)}

The third step in the evaluation process is the identification of the main sub-systems that are to be measured. Different sub-systems are identified in the literature on software evaluation. Of these the sub-systems reported by DeSanctis, Snyder and Poole (1994:323) and Stylianou, Madey and Smith (1992:37) are the most comprehensive. For PHC software the following key factors are suggested:

\section{End-user interface}

"A computer system which is perceived by users not to be useful and difficult to use, is doomed to failure regardless of how good it may be. User perception of the degree of success of a software package is the prime predictor of the successful implementation of the package" (Martin and Trumbly 1986:7). As noted by Doll and Torkzadeh (1988:259) ease of use has become increasingly important in software design. There is growing evidence that the effective functioning of an application depends on its usability.

In the PHC environment, two kinds of end-users can be identified. Firstly, there are the nurses providing PHC services in the clinics. They use the computer system mainly for data capturing, updating of patient records and reporting to management. Secondly, there are the managers at different levels who use the database to extract information for management purposes. Both structured and unstructured queries and reports must be catered for. It is important that any evaluation should take cognisance of both types of users.

\section{Functionality and features}

The range of tasks (functions) that it can perform determines the scope of any software package. Both core tasks (for example, Patient Management) and optional tasks (for example, Feeding Scheme) should be identified. The functions are determined by asking questions such as: "what does the system provide?".

Just as important as the functions, are the features of the system - the means that the functions are provided. Examples of features are capabilities such as graphic interfaces, menus, windows, etc.

\section{Organisational impact}

What is the impact of the system on the way the organisation functions and what benefits can be gained from utilising the system? This sub-system determines the value that is added to the organisation through the use of the computer system.

\section{Vendor responsibility}

This factor determines the background and commitment of the vendor to the product. Will he be able to provide the required maintenance of and support for the software? What is his financial position? There is nothing more frustrating than having an excellent system, and not knowing how to use it, or not being able to obtain help when it is required

\section{Cost}

A computer system may meet all the requirements, but if it is not affordable it is 
useless. Costs are involved in more than just the purchase price of the product. Additional hardware and software, personnel, training, support and maintenance, for example, all involve costs.

\section{Selection of key criterio for these factors}

After establishing the main sub-classes to be measured, the next step is to determine criteria for each sub-class. The selected criteria together form the evaluation instrument.

\section{End-user interface}

End-user computing satisfaction can be measured subjectively or objectively. A questionnaire completed by the users who interact directly with the system can serve as a subjective instrument. Doll and Torkzadeh (1988:268) list 12 questions broken down into content, accuracy, format, ease of use and timeliness. End-user computing satisfaction can also be measured objectively. Variables that fall within this category are response time, learning time, time required to complete a task, error rate, etc. In terms of human factors, Poston and Sexton (1992:39), propose only quantifiable factors such as performance and reliability. They warn against criteria such as "easy to use" which they consider too vague. According to them interface features such as mice, menus, windows, etc. should not be considered.

\section{Functionality and features}

The list of functions and features identified by the users during the first step of the evaluation process can serve as criteria for this sub-class. The users can be asked to rate on a certain scale to what extent a function or feature fulfils its task.

\section{Organisaional impact}

The performance of the PHC softwareuser interface must be acceptable. But this alone is insufficient. A second interface, linking the user and the larger decision-making organisation, also enters the picture. Does the software facilitate the organisation's decision-making process?

The same kind of questions that applied to the end-user interface are applicable here. The questions should be directed at management and should focus on the benefits accruing from using the computer system.

\section{Costs}

Criteria for costs are evident. It is important that all the hidden costs should be identified as well.

\section{Vendor responsibility}

The criteria related to the vendor are aimed at determining whether he will be available in the future to maintain and support his product. Stylianou, Madey and Smith (1992:39) propose a list of suggested criteria.

\section{Choice of measurement method and unit}

Some of the quantifiable criteria may be measured objectively. For instance, response time, time required to learn, mean time between failures, etc. can be measured electronically or by hand in units of time. Costs can also be measured objectively in terms of monetary units.

The other criteria such as end-user satisfaction, functionality, features, vendor, etc. should be measured by means of a questionnaire on a subjective basis. The features can be measured by means of a checklist and given a value of 1 if the feature is present and a value of 0 if it is absent. In the case of the other criteria Stylianou, Madey and Smith (1992:35) suggest that subjects should be asked to evaluate the importance of each of the evaluation criteria on a five-point Likertlike scale $(1=$ not important; $5=$ critical).

\section{Performing the evaluation}

During this step of the evaluation process, the evaluation instrument is applied to the users of the software packages. At this stage the users have been selected to take part in the experiment, trained in the use of the package and will have used the package in the normal working environment for a considerable time. If at all possible, a representative sample of nurses should be selected. This means that nurses from all regions in the province, those who are computer literate as well as those who are computer illiterate, those who work in fixed as well as those who work in mobile clinics, and managers from all levels of the information hierarchy should be selected. To obtain such a representative sample can present a problem given the time and costs involved. To obtain the best results, all the nurses should evaluate all the packages. This too can be a problem given the workload of the nurses and the length of time required for a field trail (6 to 8 weeks).

After the instrument has been applied to the software packages, the data must be analysed by means of appropriate statistical methods. By means of this method the different packages can be compared.

\section{Reporting of the results}

The evaluation process is concluded with a report on all the findings of the evaluation to top management. The report should contain a recommendation, but the final decision should be left to top management.

\section{Conclusion find Recommendations}

The complex task of software evaluation has been covered in detail and applied to the health care environment. Software evaluation was defined, different approaches towards software evaluation were discussed and the people involved in the evaluation process were identified. A seven-step approach towards software evaluation was also proposed. All the work culminated in the design of a comprehensive evaluation instrument (see Appendix A) which can be used to assess PHC software.

It is recommended that health decisionmakers invest the time and effort to work through all the proposed steps. This process may take longer to complete, but it could avoid an eventual financial disaster when purchasing a computer system that may not be suitable for the required purpose.

\section{ficknowledgement}

Acknowledgement is given to the Medical Research Council of South Africa who provided a grant for this research. 


\section{Software Evaluation Insrument}

\section{Part I - Technical information}

This part should be completed by somebody knowledgeable with information systems, software and hardware capabilities:

Software Package :

Evaluator's name :

Position :

Department :

Date :

General information

Version number :

Release date :

Vendor name :

Vendor address :

Operating system :

Other required software :

Database model :

Type of database :

Programming language :

Communication protocols :

Required hardware :

Network requirements :

Minimum configuration :

\section{Costs}

Quantity one :

Multiple copies:

Site license :

Purchase cost of packages :

Hardware costs :

Additional software costs :

Personnel costs :

Installation fees :

Training costs :

Total startup cost :

Cost for updates :

Support fees :

Consulting fees :

Total running costs :

Vendor information

Do you provide maintenance?

Do you provide technical support?

Do you provide training courses?

Do you provide a professional

application service?

Do you maintain a consulting service?

Number of years product in operation?

Number of years in design and

manufacturing of software?

Number of current installations?

List of current installations?

\section{Performance}

Time to install

Time to load

Size of installed files 
Overall how would you rate this software package in terms of the following $(1=$ non-existent, $2=$ poor, $3=$ fair, $4=$ good, $5=$ excellent)?:

Functional capabilities

Patient management

Financial management

Facilities management

Personnel management

Medical stores management

Executive information management

\section{Software features}

Contextual on-line help

Multi-level security

Audit trail

Menu layout and traversing

Search facilities

Look-up facilities (pick lists)

Graphical user interface

On-line tutorial

Documentation

Ad-hoc queries and reports

Interface to other systems (PERSAL, etc.)

User definable codes

Multi-user support

Client/server support

Distributed database support

$\begin{array}{lllll}1 & 2 & 3 & 4 & 5 \\ 1 & 2 & 3 & 4 & 5 \\ 1 & 2 & 3 & 4 & 5 \\ 1 & 2 & 3 & 4 & 5 \\ 1 & 2 & 3 & 4 & 5 \\ 1 & 2 & 3 & 4 & 5\end{array}$

$\begin{array}{lllll}1 & 2 & 3 & 4 & 5 \\ 1 & 2 & 3 & 4 & 5 \\ 1 & 2 & 3 & 4 & 5 \\ 1 & 2 & 3 & 4 & 5 \\ 1 & 2 & 3 & 4 & 5 \\ 1 & 2 & 3 & 4 & 5 \\ 1 & 2 & 3 & 4 & 5 \\ 1 & 2 & 3 & 4 & 5 \\ 1 & 2 & 3 & 4 & 5 \\ 1 & 2 & 3 & 4 & 5 \\ 1 & 2 & 3 & 4 & 5 \\ 1 & 2 & 3 & 4 & 5 \\ 1 & 2 & 3 & 4 & 5 \\ 1 & 2 & 3 & 4 & 5 \\ 1 & 2 & 3 & 4 & 5\end{array}$

\section{Part II - Dato Capturing Facilities}

This section is to be completed by a representative sample of nurses doing data capturing at the point of service. They must have used the package for a considerable time in a working environment.

Overall how would you rate this software package in terms of the following $(1=$ non-existent, $2=$ poor, $3=$ fair, $4=$ good $5=$ excellent)?:

\section{Subjective measurements}

The task to register a new patient is easy

There are convenient means to search for a patient

The application provide for all PHC services

The security of the system is sufficient

The application corresponds closely to the old way of doing things

The application ensures that entered data is valid to the extent possible

All the required indicators are catered for

It is easy to make ad-hoc queries

The format of the reports are just what is required

The application provides me with sufficient information of what is

happening in my area

It is easy to find what I need to do in the application

The amount of typing I need to do is a minimum

The quality of the on-line help is just what is required

The quality of the paper documentation is just what is required

The interaction with the system is clear and understandable

My productivity will increase by using the application

I have more time available for patient care during consultations

Overall the application is easy to use

Overall the application is easy to learn

Overall the response time of the system is good

$\begin{array}{llll}2 & 3 & 4 & 5 \\ 2 & 3 & 4 & 5 \\ 2 & 3 & 4 & 5 \\ 2 & 3 & 4 & 5 \\ 2 & 3 & 4 & 5 \\ 2 & 3 & 4 & 5 \\ 2 & 3 & 4 & 5 \\ 2 & 3 & 4 & 5 \\ 2 & 3 & 4 & 5 \\ & & & \\ 2 & 3 & 4 & 5 \\ 2 & 3 & 4 & 5 \\ 2 & 3 & 4 & 5 \\ 2 & 3 & 4 & 5 \\ 2 & 3 & 4 & 5 \\ 2 & 3 & 4 & 5 \\ 2 & 3 & 4 & 5 \\ 2 & 3 & 4 & 5 \\ 2 & 3 & 4 & 5 \\ 2 & 3 & 4 & 5 \\ 2 & 3 & 4 & 5\end{array}$

\section{Objective measurements}

Response time

Time to learn

Time to complete task

Mean time between failures

Error rate 


\section{Part III - Management Facilities}

This section is to be completed by a representative sample of managers at different levels who have used the package for a considerable time in a working environment.

Overall how would you rate this software package in terms of the following $(1=$ non-existent, $2=$ poor, $3=$ fair, $4=$ good, $5=$ excellent)?:

\section{Subjective measurements}

The system provides for all the required management functions

It is easy to make ad-hoc queries with the application

The system provides the precise information I need

The information content meet my needs

The system provides reports that seem just about exactly what I need

I am satisfied with the accuracy of the system

The output is presented in a useful format

The information is clear

I get the information I need on time

The system provides up-to-date information

I have more time available for other management tasks

Overall the application is easy to use

Overall the application is easy to learn

Overall the response time of the system is good

$\begin{array}{lllll}1 & 2 & 3 & 4 & 5 \\ 1 & 2 & 3 & 4 & 5 \\ 1 & 2 & 3 & 4 & 5 \\ 1 & 2 & 3 & 4 & 5 \\ 1 & 2 & 3 & 4 & 5 \\ 1 & 2 & 3 & 4 & 5 \\ 1 & 2 & 3 & 4 & 5 \\ 1 & 2 & 3 & 4 & 5 \\ 1 & 2 & 3 & 4 & 5 \\ 1 & 2 & 3 & 4 & 5 \\ 1 & 2 & 3 & 4 & 5 \\ 1 & 2 & 3 & 4 & 5 \\ 1 & 2 & 3 & 4 & 5 \\ 1 & 2 & 3 & 4 & 5\end{array}$

\section{Objective measurements}

Response time

Time to learn

Time to complete task

Mean time between failures

Error rate

\section{References}

DeSanctis G., Snyder J.R. and Poole M.S. 1994. The Meaning of the Interface: A functional and holistic evaluation of a meeting software system. Decision Support Systems, Vol 11, 319-335.

Doll W.J. and Torkzadeh G. 1988. The Measurement of End-User Computing Satisfation, MIS Quaterly, 259274.

Martin M.P. and Trumbly J.E. 1986. Measuring Performance of Automated Systems. Journal of Systems Management, 7-17.

Mc Donald T., Chapman R.D. and MacKenzie J. 1994. Primary Health Care Rendered from Mobile Clinics: Can Computers Help? Curationis, Vol $12,35-38$.
Moidu K., Wigertz O. and Trell E. 1992. Multi Centre Systems Analysis Study of Primary Health Care: A Study of Socio-Organizational and Human Factors, International Journal of Biomedical Computing, Vol 30, 27-42.

Mosely V. 1992. How to Assess Tools Efficiently and Quantitatively. IEEE Software, 29-32.

Poston R.M. and Sexton P. 1992. Evaluating and Selecting Testing Tools. IEEE Software, 33-42.

Stylianou A.C., Madey G.R. and Smith R.D. 1992. Selection Criteria for Expert System Shells: A Socio-Technical Framework. Communication of the ACM, Vol 35, 30-47.

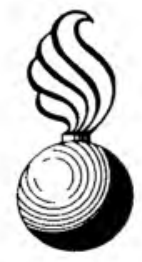

